\title{
Carcass Traits and Leather Quality Characteristics of Blackhead Ogaden Sheep Fed Different Proportions of Roughage and Concentrate Ratios
}

\author{
Fasil Negussie $^{1}$, Mengistu Urge ${ }^{1}$, Yosef Mekasha ${ }^{2}$ and Getachew Animut ${ }^{3}$ \\ ${ }^{1}$ Haramaya University, School of Animal and Range Sciences, P.O. Box 138, Dire Dawa, ETHIOPIA \\ ${ }^{2}$ International Livestock Research Institute (ILRI), P.O. Box 5689, Addis Ababa, ETHIOPIA \\ ${ }^{3}$ Agricultural Transformation Agency, Addis Ababa, ETHIOPIA \\ "Corresponding author: Fasil Negussie: E-mail: fasiln27@gmail.com
}

Received: 18 March, 2020

Revised: 04 March, 2020

Accepted: 07 May, 2020

\begin{abstract}
An experiment was conducted to assess the effect of varying level of roughage to concentrate ratios on carcass traits and leather quality characteristics of Blackhead Ogaden sheep aged 2 years (20.8 \pm 1.8 initial body weight). Twenty four lambs were blocked into 6 groups of four lambs based on initial body weight and randomly assigned within group to 4 diets. Roughage composed of natural grass hay and haricot bean hauls (50:50 ratio) and concentrate mixture composed of wheat bran (69\%) and $31 \%$ of oil seed meal (noug seed cake and cottonseed meal in the ratio of 1.1:1) were offered at roughage (R) to concentrate (C) ratios of 60R:40C, 50R:50C, 40R:60C, and 30R:70C. Roughage and supplement were offered separately and percentages of the two feeds were determined based on ad libitum consumption of individual animal on dry matter (DM) basis. After the completion of stall feeding, animals were slaughtered for carcass parameters and leather quality evaluation. Slaughter body weight, hot carcass weight, dressing percentage as a proportion of slaughter body weight, empty body weight, and total usable products are greater in group consumed 30R:70C than 60R:40C ration $(\mathrm{P}<0.05)$. Fat content and elongation percentage of leather produced from sheep consumed 60R:40C was higher $(\mathrm{p}<0.05)$ than 30R:70C. However, the other chemical and physico-mechanical quality of leather were not affect by the treatment diet $(\mathrm{P}>0.05)$. Thus, we conclude that feeding of roughage and concentrate at the ratio of 30R:70C could be recommended as better feeding strategy for better performances of finishing sheep.
\end{abstract}

Keywords: Roughage, concentrate, carcass, leather, sheep

Sheep production has a vital socioeconomic importance for many smallholders in the tropics. The large number as a component of livestock, wide distribution across various agro ecological zones and the ease to manage as compared to large ruminants indicates the significant role that sheep can play in improving the livelihoods of the societies in tropical countries (Wondwosen et al., 2013). The prevalent sheep production system in Ethiopia is traditional and live animal and carcass export relies much on young animals' offered to market from traditional pastoral and agro pastoral farming systems (Solomon et al., 2010). As a result, the weight of the live animal and carcass yield obtained per head is low (MOARD, 2007) and do not comply with the requirement for export market. Moreover, the poor productivity coupled with low off take rate (Asfaw and Jabbar, 2008; Mekuriaw et al., 2012) fails to supply the required amount to meet the increased demand for sheep meat consumption. Such carcasses are also poor in conformation and quality because of the poor muscle development. This has marginalized the bargaining power of the country in world meat, live animal and skin/ hide trade.

Previous works (kefelegn et al., 2011; Birhanu et al., 2013; Getahun, 2014) showed that better feeding practices improved body weight gain and carcass yield of indigenous sheep. According to these works, yearling

How to cite this article: Negussie, F., Urge, M., Mekasha, Y. and Animut, G. (2020). Carcass traits and leather quality characteristics of blackhead Ogaden sheep fed different proportions of roughage and concentrate ratios. J. Anim. Res., 10(3): 339-346. Source of Support: None; Conflict of Interest: None क्ष 
sheep supplemented with a mixture of concentrate and/ or better quality roughage, such as haricot bean haulms, gained weight as much as 60 compared to only $19 \mathrm{~g}$ /day in the unsupplemented group and recorded hot carcass weight of above 9 compared to $7 \mathrm{~kg} /$ head, respectively. Nonetheless, studies so far conducted did not consider the impact of different proportion of roughage to concentrate ratio on performance of sheep aged two years, and the extent to which this feeding system enable to achieve the desired export market weights, carcass yield and skin quality. Therefore, the current study was conducted to assess the effect of varying proportion of roughage and concentrate on carcass traits and leather quality parameters of Blackhead Ogaden sheep.

\section{MATERIALS AND METHODS}

\section{Experimental animals and their management}

A total of 24 Blackhead Ogaden lambs aged 2 years (estimated by dentition and information obtained from the owners) were purchased from the local market of Somali National Regional State. Experimental animals were quarantined for 3 weeks in isolated holding yards at Haramaya University to observe any development of disease or abnormal conditions and parasites. The experimental animals were vaccinated against common infectious diseases in the area (pasteurelosis and anthrax), de-wormed against internal parasites by albendazol dewormer, and sprayed with acaricides (Vetacidin 20\%) against external parasites when they were in the holding yard. After the quarantine period, the animals were placed in experimental house partitioned into individual pens (70 $\mathrm{X} 120 \mathrm{~cm}$ ) equipped with feeding trough and watering bucket and acclimated to the experimental procedures and feeds for 14 days before the commencement of the trials. After completion of stall digestibility trial, all lambs were slaughtered for carcass and skin/leather parameter studies.

\section{Experimental feeds preparation and feeding}

The experiment was conducted at Haramaya University goat farm $\left(9.0^{\circ} \mathrm{N}\right.$ latitude and $42.0^{\circ} \mathrm{E}$ longitude). Natural pasture hay and haricot bean haulms were mixed in the ratio of 50:50 and used as a basal feed (Dejen, 2010; Emebet, 2008). Haricot bean haulms of different varieties were obtained from the University's crop research and production section. The roughages were separately chopped manually to a length of approximately $5 \mathrm{~cm}$ for simplicity of mixing and to reduce selectivity by animals. The concentrate comprised $69 \%$ wheat bran and $31 \%$ oil seed meals (noug and cottonseed cakes in 1.1:1 ratio). Roughage and concentrate feeds were offered in a separate feeder. The feed was offered in two equal meals at 08:00 and 05:00 hours. Clean tap water and salt blocks were available all the time.

\section{Experimental design and treatments}

The animals were blocked into six groups of four lambs each based on initial body weight. Lambs in a block were randomly assigned to one of the four dietary treatments. Thus, a randomized complete block design (RCBD) was employed. Treatments are based on different proportions of roughage $(\mathrm{R})$ to concentrate $(\mathrm{C})$ ratio and consist of 60R:40C (60\% roughage and $40 \%$ concentrate diets feeding), 50R:50C, 40R:60C, and 30R:70C. On the first day of the experiment, feed was offered at $3 \%$ of body weight of individual animal. On the subsequent days and throughout the experiment, the proportion of roughage to concentrate was determined from animals' ad libitum intake on dry matter basis and offer was adjusted every four days.

\section{Slaughter measures}

At the end of the study, body weight (SBW) was taken after animals were fasted overnight and slaughtered by exsanguinations at the Haramaya University Abattoir. Weights of empty body (EBW), non-carcass components and hot carcass (HCW) were determined at the time of slaughter. Carcass was chilled for $24 \mathrm{hrs}$ in a refrigerator at $4^{\circ} \mathrm{C}$. The chilled carcass was weighed and suspended with hind legs on a hock gambre of $20 \mathrm{~cm}$ width and linear carcass measures (hind leg length, anterior and posterior buttock circumference of thorax, chest depth, and buttock and shoulder width) were recorded as described by Tsegay et al. (2012b) and Negussie et al. (2015a). The rib-eye muscle area of each animal was determined by tracing the cross sectional area of the $12^{\text {th }}$ and $13^{\text {th }}$ ribs after cutting perpendicular to the backbone. The left and right ribeye area was traced on a transparent waterproof paper, transferred to graph paper and the area was counted and 
computed for both sides and the mean of the two was taken. Dressing percentage (DP) was calculated as a proportion of slaughter body weight (SBW) and empty body weight (EBW) on hot carcass. Carcass of each lamb was chilled at $4{ }^{\circ} \mathrm{C}$ in a refrigerator for $24 \mathrm{~h}$. The chilled carcass was split into two equal halves by cutting through the vertebral column, both sides weighed and the left side physically dissected into lean tissue, fat, and bone components. Total usable product (TUP) was taken as the sum total weight of hot carcass weight $(\mathrm{HCW})$, total edible offal component (TEOC) and skin.

\section{Leather quality evaluation}

Skin of all animals were flayed carefully and preserved in a salt solution and transported to the Ethiopian Leather Industry Development Institute (LIDI) in Addis Ababa. Wet salting, skin and leather processing and chemical and physico-mechanical quality evaluation of leather were done according to the International Organization for standardization and Ethiopian standard authority codes. Detailed description of these methods were given in articles published earlier (Seid et al., 2012; Fasil et al., 2015).

\section{Chemical analysis}

Feed samples were analyzed for dry matter (DM), ash, organic matter $(\mathrm{OM})$ and nitrogen according to the procedures of AOAC (1990). Crude protein (CP) was estimated as $\mathrm{N} \times$ 6.25. Neutral detergent fiber (NDF), acid detergent fiber (ADF) and acid detergent lignin (ADL) were analyzed according to Van Soest and Robertson (1985).

\section{Statistical analysis}

Data of carcass, and leather quality parameters were analyzed using the general linear model procedure of SAS (2008) with a model consisting treatment and block effect. Means were separated by Tukey HSD (Tukey Honestly Significant Difference) test method.

\section{RESULTS AND DISCUSSION}

\section{Feedstuff composition}

Concentration of crude protein, neutral detergent fiber and acid detergent fiber in grass hay and haricot bean haulm
(Table 1) reflect a moderate to high stage of maturity at harvest for hay and much leaf lose in the haulm at harvesting and collection. Concentration of chemical constituents of the concentrate were as expected based on ingredients composition and the crude protein content is sufficient for fattening sheep as recommended by NRC (1985).

Table 1: Chemical composition of feedstuffs consumed by Blackhead Ogaden sheep

\begin{tabular}{|c|c|c|c|c|c|c|}
\hline Ingredients & DM & $\mathbf{O M}$ & $\mathbf{C P}$ & NDF & ADF & ADL \\
\hline $\begin{array}{l}\text { Haricot bean } \\
\text { haulm }\end{array}$ & 91.3 & 90.1 & 7.1 & 62.1 & 38.9 & 7.0 \\
\hline Hay & 90.0 & 91.3 & 7.9 & 79.3 & 43.2 & 21.0 \\
\hline Wheat bran & 89.4 & 93.5 & 18.1 & 46.3 & 11.8 & 1.5 \\
\hline Cottonseed cake & 91.8 & 92.9 & 30.7 & 37.1 & 27.7 & 7.2 \\
\hline Noug seed cake & 90.9 & 90.2 & 37.0 & 33.9 & 15.2 & 3.3 \\
\hline $\begin{array}{l}\text { Concentrate } \\
\text { mixture }\end{array}$ & 90.2 & 92.8 & 23.4 & 37.2 & 18.3 & 4.3 \\
\hline
\end{tabular}

$\mathrm{ADF}=$ acid detergent fiber; $\mathrm{ADL}=$ acid detergent lignin $\mathrm{CP}=$ crude protein; $\mathrm{DM}=$ dry matter; $\mathrm{NDF}=$ neutral detergent fiber; $\mathrm{OM}=$ organic matter.

\section{Carcass measures}

There was no significant deference between treatments in dressing percentage as a proportion of empty body weight, left half carcass length, tail and rib eye area (Table 2). Slaughter body weight, hot carcass weight, dressing percentage as a proportion of slaughter body weight, empty body weight, and total usable products are greater in group consumed 30R:70C than 60R:40C ration $(\mathrm{P}<0.05)$.

Carcass length (CL), leg length (LL) and shoulder width (SW) were not different $(\mathrm{p}>0.05)$ among the dietary treatments (Table 3). Anterior buttock circumference $(\mathrm{ABC})$ and buttock width $(\mathrm{BW})$ were higher $(\mathrm{P}<0.05)$ for sheep consumed 40R:60C and 30R:70C ration than groups fed with 60R:40C and 50R:50C, respectively. Greater $(\mathrm{P}<0.05)$ posterior buttock circumference $(\mathrm{PBC})$ was demonstrated by sheep in 30R:70C than in 60R:40C and 50R:50C; the value for 40R:60C also was significantly higher $(\mathrm{P}<0.05)$ compared to 60R:40C. Chest depth $(\mathrm{CD})$ was the highest for 30R:70C, the lowest for 60R:40C and intermediate for the other treatment groups. Group fed 
Table 2: Effect of different levels of roughage and concentrate ratios on Slaughter characteristics

\begin{tabular}{|c|c|c|c|c|c|c|}
\hline \multirow{2}{*}{ Parameters } & \multicolumn{4}{|c|}{ Dietary treatments } & \multirow{2}{*}{ SEM } & \multirow{2}{*}{ P-value } \\
\hline & 60R:40C & 50R:50C & 40R:60C & 30R:70C & & \\
\hline SBW (kg) & $25.6^{\mathrm{b}}$ & $26.2^{\mathrm{ab}}$ & $28.3^{\mathrm{ab}}$ & $29.0^{\mathrm{a}}$ & 0.07 & 0.0143 \\
\hline EBW $(\mathrm{kg})$ & $20.9^{\mathrm{b}}$ & $22.3^{\mathrm{ab}}$ & $23.7^{\mathrm{ab}}$ & $24.6^{\mathrm{a}}$ & 0.65 & 0.0065 \\
\hline $\mathrm{HCW}(\mathrm{kg})$ & $10.7^{\mathrm{b}}$ & $11.7^{\mathrm{ab}}$ & $12.6^{\mathrm{ab}}$ & $13.8^{\mathrm{a}}$ & 0.50 & 0.0202 \\
\hline HDP (SBW basis) & $41.3^{\mathrm{b}}$ & $44.5^{\mathrm{ab}}$ & $44.6^{\mathrm{ab}}$ & $47.6^{\mathrm{a}}$ & 1.05 & 0.0097 \\
\hline HDP (EBW basis) & 50.7 & 52.7 & 53.0 & 55.9 & 1.32 & 0.0802 \\
\hline TUP (kg) & $18.4^{\mathrm{b}}$ & $19.2^{\mathrm{ab}}$ & $20.8^{\mathrm{a}}$ & $22.1^{\mathrm{a}}$ & 0.71 & 0.0066 \\
\hline Tail (kg) & 0.91 & 0.95 & 0.99 & 1.19 & 0.12 & 0.1601 \\
\hline LH $(\mathrm{kg})$ & 5.10 & 5.41 & 5.60 & 5.80 & 0.32 & 0.4626 \\
\hline $\operatorname{REA}\left(\mathrm{cm}^{2}\right)$ & 8.9 & 9.2 & 10.2 & 10.9 & 0.83 & 0.1556 \\
\hline
\end{tabular}

Means within a row without common letter differ $(\mathrm{P}<0.05)$; $\mathrm{SEM}=$ standard error of mean; ${ }^{1} \mathrm{R}$ and $\mathrm{C}$ refer to roughage and concentrate, respectively. $\mathrm{SBW}=$ Slaughter body weight; $\mathrm{HCW}=$ hot carcass weight; $\mathrm{EBW}=$ Empty body weight; $\mathrm{TUP}=$ Total usable products; $\mathrm{LH}=$ Left hot carcass; REA = rib-eye muscle area

Table 3: Effect of different levels of roughage and concentrate ratios on carcass dimensional and chemical composition of Blackhead Ogaden sheep

\begin{tabular}{|c|c|c|c|c|c|c|}
\hline \multirow{2}{*}{$\begin{array}{l}\text { Carcass } \\
\text { Dimensions (cm) }\end{array}$} & \multicolumn{4}{|c|}{ Dietary treatments } & \multirow{2}{*}{ SEM } & \multirow{2}{*}{ P-value } \\
\hline & 60R:40C & 50R:50C & 40R:60C & 30R:70C & & \\
\hline Carcass length & 55.0 & 56.0 & 61.4 & 62.2 & 3.87 & 0.5514 \\
\hline Leg length & 30.6 & 30.8 & 32.3 & 36.0 & 1.85 & 0.1696 \\
\hline PBC & $39.8^{\mathrm{c}}$ & $44.7^{\mathrm{bc}}$ & $52.3^{\mathrm{ab}}$ & $53.8^{\mathrm{a}}$ & 2.13 & 0.0008 \\
\hline $\mathrm{ABC}$ & $36.3^{b}$ & $42.3^{\mathrm{ab}}$ & $49.6^{\mathrm{a}}$ & $47.8^{\mathrm{a}}$ & 2.28 & 0.0023 \\
\hline Buttock width & $9.3^{\mathrm{b}}$ & $10.5^{\mathrm{b}}$ & $13.2^{\mathrm{a}}$ & $13.7^{\mathrm{a}}$ & 1.16 & 0.0284 \\
\hline Shoulder width & 16.2 & 16.6 & 17.2 & 17.5 & 0.44 & 0.4534 \\
\hline Chest depth & $24.3^{\mathrm{b}}$ & $26.0^{\mathrm{ab}}$ & $26.3^{\mathrm{ab}}$ & $28.0^{\mathrm{a}}$ & 0.76 & 0.0153 \\
\hline \multicolumn{7}{|l|}{ Composition } \\
\hline Lean (\%) & $65.0^{\mathrm{a}}$ & $60.5^{\mathrm{ab}}$ & $57.2^{\mathrm{b}}$ & $56.5^{\mathrm{b}}$ & 5.07 & 0.0170 \\
\hline Bone $(\%)$ & 25.5 & 28.1 & 27.3 & 26.8 & 1.67 & 0.1375 \\
\hline Fat (\%) & $9.5^{\mathrm{b}}$ & $11.4^{\mathrm{ab}}$ & $15.5^{\mathrm{ab}}$ & $16.7^{\mathrm{a}}$ & 1.15 & 0.0335 \\
\hline Meat:bone & 2.5 & 2.2 & 2.1 & 2.0 & 0.14 & 0.3003 \\
\hline
\end{tabular}

Means within row without a common letter differ $(\mathrm{P}<0.05)$; $\mathrm{SEM}=$ standard error of mean; ${ }^{1} \mathrm{R}$ and $\mathrm{C}$ refer to roughage and concentrate, respectively; $\mathrm{PBC}=$ Posterior buttock circumference; $\mathrm{ABC}=$ Anterior buttock circumference.

with 60R:40C diet has produced leaner $(\mathrm{p}<0.05)$ carcass than those fed with 40R:60C and 30R:70C diets (Table 3). Conversely, sheep in 60R:40C produced carcass with lower fat content than those in 30R:70C, but value was similar for the other treatment groups.

\section{Non carcass components}

Weight of all non carcass components did not show differences $(\mathrm{P}>0.05)$ among treatments due to the different roughage to concentrate ratios (Table 4 ).

\section{Chemical quality of leather}

Fat content of leather produced from sheep consumed 30R:70C was significantly higher $(\mathrm{P}<0.05)$ compared to those fed with $60 \mathrm{R}: 40 \mathrm{C}$, but value was similar with other treatment groups (Table 5). Chromic oxide and moisture content of leather was not affected $(\mathrm{P}>0.05)$ due to the varying proportion of roughage and concentrate.

\section{Physico-mechanical tests of leather}

In the present study, proportion of roughage to concentrate 
Table 4: Effect of different levels of roughage and concentrate ratios on non-carcass characteristics

\begin{tabular}{|c|c|c|c|c|c|c|}
\hline \multirow{2}{*}{ Parameters (kg) } & \multicolumn{4}{|c|}{ Dietary treatments } & \multirow{2}{*}{ SEM } & \multirow{2}{*}{ P-value } \\
\hline & 60R:40C & 50R:50C & 40R:60C & 30R:70C & & \\
\hline Liver & 0.34 & 0.35 & 0.37 & 0.38 & 0.07 & 0.4310 \\
\hline Heart & 0.10 & 0.11 & 0.13 & 0.13 & 0.01 & 0.6523 \\
\hline Kidney & 0.10 & 0.11 & 0.12 & 0.12 & 0.01 & 0.5110 \\
\hline Lung + trachea & 0.33 & 0.38 & 0.39 & 0.40 & 0.05 & 0.0924 \\
\hline Head & 1.60 & 1.66 & 1.54 & 1.42 & 0.01 & 0.2667 \\
\hline Skin & 3.19 & 2.88 & 3.18 & 3.20 & 0.49 & 0.1339 \\
\hline Blood & 1.23 & 1.21 & 1.37 & 1.35 & 0.04 & 0.6088 \\
\hline GIT full & 6.17 & 5.91 & 6.24 & 5.81 & 0.65 & 0.2095 \\
\hline Digesta & 4.70 & 4.44 & 4.57 & 4.41 & 0.57 & 0.1998 \\
\hline GIT empty & 1.46 & 1.50 & 1.67 & 1.47 & 0.25 & 0.2437 \\
\hline Feet & 0.55 & 0.54 & 0.60 & 0.61 & 0.05 & 0.5237 \\
\hline Testicles + genitals & 0.38 & 0.38 & 0.40 & 0.41 & 0.04 & 0.0528 \\
\hline
\end{tabular}

$\mathrm{SEM}=$ standard error of mean; ${ }^{1} \mathrm{R}$ and $\mathrm{C}$ refer to roughage and concentrate, respectively.

Table 5: Effect of different levels of roughage and concentrate ratios on chemical quality of leather

\begin{tabular}{|c|c|c|c|c|c|c|}
\hline \multirow{2}{*}{ Parameters } & \multicolumn{4}{|c|}{ Dietary treatments ${ }^{1}$} & \multirow{2}{*}{ SEM } & \multirow{2}{*}{ P-value } \\
\hline & 60R:40C & 50R:50C & 40R:60C & 30R:70C & & \\
\hline Fat (\%) & $8.2^{\mathrm{b}}$ & $9.1^{\mathrm{ab}}$ & $9.6^{\mathrm{ab}}$ & $9.8^{\mathrm{a}}$ & 0.36 & 0.0223 \\
\hline Chromic oxide (\%) & 3.3 & 3.6 & 3.4 & 3.8 & 0.16 & 0.1596 \\
\hline Moisture at crust (\%) & 15.8 & 15.3 & 14.9 & 14.6 & 0.48 & 0.4242 \\
\hline Moisture at blue (\%) & 76.6 & 75.1 & 76.0 & 77.5 & 0.44 & 0.8582 \\
\hline
\end{tabular}

Means within a row without common letter differ $(\mathrm{P}<0.05)$; SEM $=$ standard error of mean; ${ }^{1} \mathrm{R}$ and $\mathrm{C}$ refer to roughage and concentrate, respectively.

Table 6: Effect of different levels of roughage and concentrate ratios on physico-mechanical quality of leather

\begin{tabular}{|c|c|c|c|c|c|c|}
\hline \multirow{2}{*}{ Parameters } & \multicolumn{4}{|c|}{ Dietary treatments } & \multirow{2}{*}{ - SEM } & \multirow{2}{*}{ P-value } \\
\hline & 60R:40C & 50R:50C & 40R:60C & 30R:70C & & \\
\hline Shrinkage temperature $\left({ }^{\circ} \mathrm{C}\right)$ & $>100$ & $>100$ & $>100$ & $>100$ & 0.00 & $=$ \\
\hline Thickness (mm) & 1.07 & 1.10 & 1.11 & 1.22 & 0.06 & 0.056 \\
\hline Tensile strength $\left(\mathrm{N} / \mathrm{mm}^{2}\right)$ & 18.2 & 19.0 & 18.1 & 18.6 & 0.88 & 0.881 \\
\hline Elongation (\%) & $69.7^{b}$ & $70.4^{\mathrm{ab}}$ & $77.0^{\mathrm{ab}}$ & $82.7^{\mathrm{a}}$ & 2.74 & 0.014 \\
\hline Mean tear force $(\mathrm{N})$ & 36.1 & 39.1 & 35.6 & 36.5 & 2.39 & 0.534 \\
\hline Tear strength $(\mathrm{N} / \mathrm{mm})$ & 30.7 & 35.3 & 32.3 & 33.6 & 1.59 & 0.248 \\
\hline Distension at burst (mm) & 11.8 & 11.7 & 11.3 & 11.0 & 0.24 & 0.446 \\
\hline Average load at burst (N) & 383.8 & 388.0 & 346.5 & 312.0 & 18.9 & 0.441 \\
\hline Tear load PRB (N) & 33.9 & 38.7 & 36.7 & 32.9 & 2.32 & 0.316 \\
\hline Tear load PPB (N) & 38.4 & 39.5 & 34.5 & 40.0 & 2.83 & 0.606 \\
\hline Water absorption (\%) & 110.2 & 110.5 & 104.9 & 110.5 & 5.06 & 0.817 \\
\hline
\end{tabular}

Means with different superscript in a raw are significantly different; SEM= standard error of mean; $\mathrm{PRB}=$ parallel to the back bone; $\mathrm{PPB}=$ perpendicular to the back bone; ${ }^{1} \mathrm{R}$ and $\mathrm{C}$ refer to roughage and concentrate, respectively.

in the diets did not show significant effect $(\mathrm{p}>0.05)$ on the physico-mechanical properties of sheep leather except the elongation percentage, which was higher $(p<0.05)$ for 30R:70C than 60R:40C, but was similar ( $>0.05$ ) to other treatment groups (Table 6).

\section{Carcass measures}

Previous studies conducted to evaluate effect of feeding different ratio of forage to concentrate demonstrated variable results with respect to carcass parameters 
(Seethalakshim et al., 2008; Nagireddy et al., 2012). In the present study, most of the slaughter parameters and hot carcass weight and total usable part (TUP) were affected by difference in roughage to concentrate ratios. However, tail weight, half carcass and rib-eye muscle area did not affect by dietary variations. Higher TUP of sheep consumed 40R:60C and 30R:70C revealed that increased proportion of concentrate in the diet increases the quantity and proportion of usable carcass components. Similarly, Greater dressing percentage for lambs fed diets with 30R:70C might be a consequence of significant differences in ADG and relatively better FCE, which in turn resulted in greater slaughter and carcass weight. In line with these findings, Jabbar and Anjum (2008) noted increased dressing percentage with increasing proportion of concentrate in the diets. Contrary to this finding, Fimbres et al. (2008) reported lack of differences in carcass weight and dressing percentage among treatment groups fed varying level of concentrate.

Sheep consumed high roughage diets had higher percentage of lean meat and low proportion of fat as compared to groups fed with low roughage diets. Higher content of carcass fat is associated with high concentrate complete feed in intensive feeding, whereas, increasing roughage component in composite ration under intensive feeding will provide leaner meat (Seethalkshmi, 2008) Contrary to these finding, Nagireddy et al. (2012) noted that growing ram lambs fed diets consisting different proportion of roughage to concentrate rations did not differ in their dissected lean, bone and inter muscular fat weight, which could be an attribute of breed and age difference among the experimental animals used. The lack of significant differences in the proportion of bone across all treatment diets in this experiment were expected, since the animals were slaughtered at older age (nearly 2 years and 4 months) and bones at this stage were fully developed to support body masses. In this regard, Anous (1991) noted that body composition in terms of dissectible components (muscle, fat and bone) changes as animals grow from birth to maturity and follows the order that the growth of bone reaches its peak first, followed by muscle and adipose tissues, respectively (Snowder, 1994). Similarly, weight of offal components with low metabolic activity varied slightly with diets, given that these components are matured early (Joy et al., 2008) and significant difference in weight among such organs is not expected. Previous studies also noted lack of significant difference in the weight of non carcass components of lambs consumed varying level of roughage and concentrate (Seethalakshmi et al., 2008; Nagireddy et al., 2012).

\section{Leather characteristics}

In the present study, animals fed with high level of concentrate displayed better fat liquor accepting capacity than those consumed low concentrate diet implying that the leather produced is more waterproof, and can prevent the fiber from breakage due to friction (Vicent, 2007). Generally, the fat content values $(8.23-9.82 \%)$ in the present study is within the range of the minimum requirement (4-10\%) for upper leather production (Gerhard, 1996). Generally, the chrome oxide content at crust stage of the leather was in agreement with the Ethiopian standard quality requirement for garment leather, which is $2.5 \%$ (QSEA, 2005c). Although there was no trend in the value of chrome oxide content in the present study, Stosic (1994) reported that goats consumed low level of concentrate had significantly higher contents of chrome oxide than those fed diet containing high level of concentrate. The moisture content at crust level of the leather did not affect by the ratio of roughage to concentrate in the diet and it was above the minimum (12\%) requirement by the Ethiopian quality standards authority-(ES 1195:2005).

The shrinkage temperature values in this study was $>100{ }^{\circ} \mathrm{C}$ for all analyzed samples which was above the minimum requirement $\left(90{ }^{\circ} \mathrm{C}\right)$ of the Ethiopian quality standard authority (ES ISO 3380:2005) confirming that it was within the recommended value of chrome tanned leather. Since it depend on the type and amount of tanning and re-tanning agent while processing skin (Bitilisli et al., 2004), the value obtained indicates that the leather produced from the sheep breed comply with the tanning procedures employed. Thickness of the leather was not statistically different among treatments, but the magnitude is higher in groups consumed ration with higher concentrate proportion. This is in agreement with the result of earlier work (Tsegay et al., 2012a) in the same sheep breed that show leather produced from lambs supplemented with higher level of concentrate had higher thickness than those consumed ration with low level of concentrate. According to the standard required by the quality of leather industry BASE (2004), the minimum 
tensile strength value and acceptable range of percentage elongation for the production of quality garment leather are $19.6 \mathrm{~N} / \mathrm{mm}^{2}$ and $40-80 \%$, respectively, in which the present values fall. Higher concentrate feeding tends to positively improve these parameter, which is in agreement with earlier work using the same breed (Tsegay et al., 2012a). Mean force $(\mathrm{N})$, tear resistance $(\mathrm{Nmm})$, distention $(\mathrm{mm})$ and load at burst $(\mathrm{N})$ were not affected by the level of concentrate in the dietary treatments, but the numerical values were higher for group of animal fed with equal proportion of roughage and concentrate $(50: 50)$ than the lower and higher proportion of concentrate in the diets. The result of this study showed that the values for Mean force and tear resistance were much higher than the values reported by Tsegay et al. (2012a) for sheep and Sied et al. (2012) for goat. This indicates that the performance of leather obtained at all levels of supplementation from the present study was better when multi directional force was applied.

\section{CONCLUSION}

The present study revealed that increasing proportion of concentrate in the diet improved carcass trait performances of the animals. Although increasing proportion of concentrate did not yield significant improvement in the quality parameters of the leather produced, lambs in all treatment groups produced leather that fulfilled the chemical and physico-mechanical quality parameters required by the leather industry in Ethiopia. Therefore, it can be conclude that roughage and concentrate of about 40:60 could be used in the ration of Blackhead Ogaden sheep for achieving better carcass traits and fulfilling the quality of leather under Ethiopian standards.

\section{ACKNOWLEDGMENTS}

We would like to thank the National Agricultural Research Fund (NARF) and Ministry of Education for the financial support and Haramaya University for allowing use of research facilities.

\section{REFERENCES}

Anous, M.R. 1991. A comparative study of muscle-bone relationship in the hind lamb of goats and sheep. J. Anim. Prod., 53: 81-87.
AOCA (Association of Official Analytical Chemists), 1990. Official Methods of Analysis, $15^{\text {th }}$ ed. Association of Official Analytical Chemists, Washington DC.

Asfaw, N. and Jabbar, M. 2008. Livestock ownership, commercial off-take rates and their determinants in Ethiopia. Research Report 9. ILRI (International Livestock Research Institute), Nairobi, Kenya, pp. 52.

Baden Aniline and Soda Factory B A S F 1984. $2^{\text {nd }}$ ed. BASF, pp. 441.

Birhanu, T., Getachew, A. and Mengistu, U. 2013. Effect of green prosopis juliflora pods and noug seed cake (Guizotia abissynica) on digestibility and performance of Blackhead Ogaden sheep fed hay as a basal diet. Sci. Technol. Art Res. J., 2: 38-47.

Dejen, A. 2010.The Effect of feeding different proportions of Maize Stover and Haricot Bean (Phaseolus Vulgaris) haulms supplemented with mixtures of concentrate diet on the performance of hararghe highland goats. M.S. thesis, Haramaya University, Haramaya, Ethiopia.

Emebet, L. 2008. Supplementation of Blackhead Ogaden sheep fed haricot bean (Phaseolus vulgaris) haulms with mixtures of wheat bran and brewers dried grain: effects on feed utilization, live weight gain and carcass parameters. M.S. thesis, Haramaya University, Haramaya, Ethiopia.

Fimbres, H., Hernandez, G.V.. Pivon, R.F.J. Kawas, R.J and $\mathrm{Lu}$, C.D. 2008. Productive performance and carcass characteristics of lambs fed finishing ration containing various forage levels. Small Rumin. Res., 43: 283-288.

Fasil, N. W., Mengistu, U. L., Yosef, M., and Getachew, A.M., 2015. Effects of different feeding regimes on leather quality of finished blackhead ogaden sheep. Sci. Technol. Arts Res. $J ., 4(4):$ 222-227.

Getahun K. 2014. Effect of concentrate supplementation on performances of Ethiopian lowland Afar and Blackhead Ogaden lambs. Anim. Vet. Sci., 2: 36-41.

Jabbar, M.A. and Anjum, M.I. 2008. Effect of diet with different forage to concentrate ratios for fattening of Lohi lambs. Pakistan Vet. J., 28: 150-1 52.

Kefelegn, K., Tsegay, T., Mengistu U. and Yoseph, M. 2011. Analysis of growth performance data in sheep using fixed and random regression models. Livest. Res. Rural Develop., Volume 23, Article \#208. Retrieved January 2, 2019, from http://www.lrrd.org/lrrd23/10/kefe23208.htm

Mekuriaw, S., Mekuriaw, Z., Taye, M., Yitayew, A. Assefa, H. and Haile, A. 2012. Traditional management system and farmers' perception on local sheep breeds (Washera and Farta) and their crosses in Amhara Region, Ethiopia. Livest. Res. Rural Develop., Volume 24, Article \#4. Retrieved May 27, 2015, from http://www.lrrd.org/lrrd24/1/meku24004.htm 
MOARD (Ministry of Agriculture and Rural Development). 2007. Livestock Development Master Plan Study. Volume K: Hides and Skins. Addis Ababa, Ethiopia.

Nargierddy, N.K., Yerradoddi, R.R. Micheal, B. Devanaboyina, N. Thamatam, M. Belum, V.S. and Chintalapani, R.D. 2012. Growth performance and carcass characterstics of growing ram lambs fed sweet sorghum baggase based complete rations varying in roughage to concentrate ratios. Trop. Anim. Health Prod., 7: 1717-1724.

SAS., 2008. SAS user's Guide Virsion 9.1.3. SAS Institute Inc. Cary. NC, USA.

Seethalakshmi, M.K., Sundaram, S.M. Kumarja, R. Sivakumar, T. Gnanaraj P.T. and Murugan, M. 2008. Carcass characteristics of Madras Red lambs fed diets of varying level forage and concentrate. J. Vet. Anim. Sci., 39: 10-13.

Seid, M., Mengistu, U.L., Getachew, A.M., Kassahun, A. Girma, A. and Arthur, L. G. 2012. Effects of level of concentrate supplementation on growth performance of Arsi-Bale and Boer x Arsi-Bale male goats consuming low quality grass hay. Trop. Anim. Health Prod., 44: 1181-1189.

Snowder, G.D. and Fiel, H.A. 1994. Carcass characteristics and optimal slaughter weight in four breeds of sheep. J. Anim. Sci., 72: 932-937.

Solomon, G., Azage, T., Berhanu G. and Dirk, H. 2010. Sheep and goat production and marketing systems in Ethiopia: characteristics and strategies for improvement. IPMS working paper No. 23, Addis Ababa, Ethiopia.

Stosic, P. 1994. Biological factors influencing the nature of goat skin and leather. M.S. thesis, University of Leicester, UK.

Tripathi, M.K., Karim, S.A., Chaturvedi, O.H. and Singh, V.K. 2006. Effect of ad libitum tree leaves feeding with varying levels of concentrate on intake, microbial protein yield and growth of lambs. Livest. Res. Rural Develop., Volume 18, Article \#179. Retrieved February 28, 2015, from http://www. lrrd.org/lrrd18/12/trip18179.htm
Tsegay, T., Mengistu, U. L. and Yosef, M. 2012a. Skin/leather quality of indigenous and crossbred (Dorper x Indigenous) F1 sheep. Livest. Res. Rural Develop., Volume 24, Article \#56. Retrieved October 2, 2013, from http://www.lrrd.org/ lrrd24/4/tek124056.htm x

Tsegay, T., Mengistu, U.L. and Yosef, M. 2012b. Carcass measurements, conformation and composition of indigenous and crossbred (Dorper $\mathrm{x}$ indigenous) F1 sheep. Pakistan $J$. Nutr., 11: 1055-1060.

Van Soest, P.J. and Robertson, B.J. 1985. Analysis of forages and fibrous foods. Lab Manual for Animal Science. Department of Animal Science, Cornell University, Ithaca, New York, USA.

Vicent, V., 2007. Chemistry of leather. Retrieved on August 25 2013 from http://www.leatherbeltdirect.com

Wondwosen, A., M. Solomon and T. Adugna, 2010. Supplementation of cottonseed, linseed, and noug seed cakes on feed intake, digestibility, body weight, and carcass parameters of Sidama goats. Trop. Anim. Health Prod., (42): 623-631.

Wondwosen, B.A., Solomon, S. and Yosef, M. 2013. Effect of substitution of concentrate mix with Sesbania sesban on intake, digestibility, body weight change and carcass parameters of Arsi-Bale sheep fed a basal diet of native grass hay. Trop. Anim. Health Prod., 45: 1677-1685.

Yusuf, A.O., Bawala, O.T. and. Adegbenjo, F.D 2012. Performance and digestibility of West African Dwarf sheep fed varying level of forage and concentrate ratio. Adv. Agric. Biotechnol., 2(12): 12-15. 